\title{
The Effect of Social Media on Society
}

\author{
Mulugeta Deribe Damota \\ Department of Psychology, College of Education and Behavioral Studies, \\ Madda Walabu University, Bale Robe, Ethiopia
}

\begin{abstract}
Social media is the collective of online communications channels dedicated to community-based input, interaction, content-sharing and collaboration. The general purpose of this review is to provide detail information about the impact of social media on society. A lot of studies indicated social media has both positive and positive outcomes. Some of the positive outcomes are, for example, Socialization and Communication; enhance learning opportunities and accessing health related information. Depression, anxiety, catfishing, bullying, terrorism, and criminal activities are some of the negative sides of social media on societies. Generally, when peoples use social media for appropriate purpose and predetermined goals the outcome will be positive and the reverse is true for negative side effects. So as to decrease and save the societies from its negative side effect and encourage the positive ones, all concerned bodies should have to work collaboratively.
\end{abstract}

Key terms: Effect social media, society

DOI: $10.7176 / \mathrm{NMMC} / 78-02$

\section{Introduction}

\section{Background of the seminar}

Social media are applications that enable people to interact with each other and build social networks that increase social capital (Barnes, 2008). For comm, 2010, Social media describes how publishers can distribute their messages to thousands of people, encouraging them to build strong connections and firm loyalty. Martn, (2008) \& Lusk, (2010) share the same concept of social media. To them social media is the use of Facebook, Blogs, Twitter, My Space and LinkedIn for the purpose of communication, sharing photos as well as videos.

Kaplan (2010) as cited in Ghulam et al., 2014 described in his study that social media is a set of internet based application that constructs on the ideological and technological foundation of wed and that permit the design and exchange of user generated content.

When it is used consciously, it is a beneficial social networking site for young people. For example, according to,Faudree (2009), Facebook has five basic advantages: (1) Facebook is a social networking site which students use frequently when they are bored, (2) Facebook is a way of communication with others members, (3) Facebook is an environment in which students feel themselves relaxed, (4) Facebook provides students to support each other and learn their personal identities, (5) Facebook is a public sphere which can be observed by school administrations and other members.

On the other hand, when children and teens spend more time on social media, they may develop many problems. For example Dube (2016) study result indicates, prolonged and excessive use of social media presents dangers i.e. suffering from mental health issues. Davila et al., 2009 also identified social media behavior and posts can be useful identifiers or predictors of depression.

Multiple studies have begun to focus on the disturbing association between online social networking and a variety of negative feelings and psychiatric disorders. According to Dube, the most pronounced of negative feelings and psychiatric disorders are: decreased self-esteem (which often works hand in hand with eating disorders and body dysmorphia), anxiety, depression/depressive symptoms, a feeling of a lack of connection, feelings of inferiority, deterioration in concentration and other symptoms of Attention Deficit Hyperactivity Disorder (ADHD), and Addiction to social media are the significant ones.

Social media can be also a source of mutilation. Sander and Thomas (2013) in their study identified two types of mutilation: Cultural, social-psychological and cognitive: forms of "Attention Deficit (Disorder)" and Business and macro-economic: forms of "Financial Deficit".

Now a days Majority of adolescent is shifting speedily from electronic media like as television viewers and radio listeners to the social media among all age of group. Because of their limited capacity for self-regulation and susceptibility to peer pressure, adolescents are at some risk as they navigate and experiment with social media. Recent research indicates that there are frequent online expressions of offline behaviors, such as bullying, clique-forming, and sexual experimentation, that have introduced problems such as cyber bullying, privacy issues, sexting, Internet addiction and concurrent sleep deprivation. (Patchin et al., 2006).

\section{Objective}

General objective

The general purpose of this review is to provide detail information about the impact of social media on society. 


\section{Specific objectives}

- To analyze the influence of social media on society

- To elucidate the positive and dark sides of social media

- To recommend some measure for proper use of social media in right direction to inform and educate the people

\section{Review on social media}

\section{Concepts and natures of social media}

According to Junco et al., (2010), social media are a collection of internet websites, services, and practices that support collaboration, community building, participation, and sharing".

As Andres (2010) cited in Ghulam et al., 2014 described in his study that social media is a set of internet based application that constructs on the ideological and technological foundation of wed and that permit the design and exchange of user generated content.

Shrestha lucky (2013) described that social media is means of connections among people in which they create, share, and exchange information and ideas in virtual communities and networks.

\section{Benefits of Using Social Media}

Social media has many benefits for adolescent students. Here below some of them are discussed.

\section{Socialization and Communication}

Social media sites allow teens to accomplish online many of the tasks that are important to them offline: staying connected with friends and family, making new friends, sharing pictures, and exchanging ideas (Ito, 2008). Different researches indicated Social media participation can offer adolescents deeper benefits that extend into their view of self, community, and the world, including: Opportunities for community engagement through raising money for charity and volunteering for local events, including political and philanthropic events; enhancement of individual and collective creativity through development and sharing of artistic and musical endeavors; growth of ideas from the creation of blogs, podcasts, videos, and gaming sites; expansion of one's online connections through shared interests to include others from more diverse backgrounds(such communication is an important step for all adolescents and affords the opportunity for respect, tolerance, and increased discourse about personal and global issues); and fostering of one's individual identity and unique social skills(Boyd, 2007; Boyd, 2008).

\section{Enhanced Learning Opportunities}

As different studies indicated social media enhance students' learning opportunities. Middle and high school students are using social media to connect with one another on home work and group projects (Boyd, 2008). For example, Facebook and similar social media programs allow students to gather outside of class to collaborate and exchange ideas about assignments. According to Borja, 2005, some schools successfully use blogs as teaching tools, which has the benefit of reinforcing skills in English, written expression, and creativity.

\section{Accessing Health Information}

Adolescents are finding that they can access online information about their health concerns easily and anonymously. Lehart, 2010, in his study indicated excellent health resources are increasingly available to youth on variety of topics of interest to this population, such asexually transmitted infections, stress reduction, and signs of depression. Adolescents with chronic illnesses can access Websites through which they can develop supportive networks of people with similar conditions (Lehart, 2010). The mobile technologies that teens use daily, namely cellphones, instant messaging, and text messaging, have already produced multiple improvements in their health care, such as increased medication adherence, better disease understanding, and fewer missed appointments (Krishna,2009).

\section{Risks of using social media}

\section{Social Media and Psychological Issues}

Several supporting ideas showing how social media, specifically, Facebook can lead to psychological problems. It's clear that social media has negative personal impacts; enabling young people to over analyze and criticize themselves as well as their problems.

\section{Facebook Depression}

Several researchers have proposed a new phenomenon called "Facebook depression', which is defined as depression that develops when individuals spend an excessive amounts of time on social media sites, such as Facebook, and then begin to exhibit classic symptoms of depression(Jackob ,2015). Seeking acceptance and 
staying connected with peers is an important element of social life. However, the intensity of the online world, which requires constant engagement, creates a factor of self-awareness that may trigger depression in some people. As with offline depression, people who suffer from Facebook depression are at risk for social isolation and sometimes turn to risky Internet sites and blogs for 'help' that may promote substance abuse, unsafe sexual practices, aggressive and self-destructive behaviors."(Jackobs, 2014).

\section{Social Media and Anxiety}

In addition to being a source of depression and anxiety, social media is also a common source of stress to its users. A survey performed on 7,000 mothers, found that $42 \%$ of mothers using the photo-sharing site, reported occasionally suffering from Stress (O'keeffe\&Clarke, 2011). Social media causes depression anxiety in two ways. Chronic stress causes depression and anxiety. Being constantly alert for new social media messages, to your instinctive fight or flight limbic system, is the same as being on continuous alert for predators, which causes a release of the stress hormone cortisol (Jackobs, 2014)

According to jackob, Primarily because social media promotes putting up a facade that highlights all the fun, excitement and success we seem to enjoy but tells very little about where we are struggling in our day to day life on a deeper level and leads to experience of false intimacy. So to fit in, in our profiles we try to portray perfectly happy and trendy facades because that's what we see others doing. As a result, our profiles reflect how we want to be perceived, rather than showing an honest picture of who we truly are.

\section{Social Media and Catfishing}

When people focus so much time on social media networks that real life relationships begin to suffer (Saedi, 2012). In doing this our more important relationships with our loved ones and close family members suffer because more of our time and effort is put into the illusion of social media. The term Catfish describes people who create fake social networking profiles, and "catfishing" is the process of befriending strangers online while using a fake or stolen identity. It is a deceptive act and it has ruined marriages, relationships and the emotional wellbeing of many people.

\section{Social Media and Criminal Activities}

Some of criminal activities related to social media are the following

\section{Social Media and Bullying}

Cyber bullying has become a major issue among youths in the last couple of decades, as it allows its victim's to post things in front of their peers and humiliate them. Bullying is defined as an aggressive act that is carried out by a group or an individual repeatedly and over time against a victim who cannot easily defend him or herself (Bannink et al., 2014). According to Campbell, 2005, with the use of Internet and mobile phones, a new form of bullying has emerged, often called 'cyber bullying'. In cyber-bullying, aggression occurs via electronic method, via the Internet and especially through social media (Bannink et al., 2014).

\section{Social Media and Terrorism}

Another dangerous aspect of social media is the rapid adoption of this medium by terrorists groups. In the last couple of decades, incidents of Islamic terrorism have occurred on a global scale, not only in Muslim-majority countries, but also in Europe, Russia, and the United States. Terrorism has been using social media for their benefit for gathering information, for recruiting members, for fund raising, and for propaganda schemes (Weimann, 2008).

According to Weimann, terrorists started using the Internet almost 16 years ago. Ever since then, monitoring the use of the Internet and online platforms use by terrorist groups has skyrocketed from 12 to over 9,800 terrorist web sites as Weimann stated.

\section{Social Media and Criminal Activities}

In order to establish a link between terrorism and social media, we need to assess the different profiles new recruits can be grouped into two (Bhui et al, .2014). The first groups of people that easily join radical groups are isolated people. The second category of people includes people with emotional problems such as depression and the last reason why some join terrorist groups is because these radical groups make them feel important.

The psychological issues such as depression, isolation and unstable personality discussed above make it easier for terrorists group to obtain new recruits. From the previous sections, one can deduce that social media is one of the many sources of emotional issues. Therefore social media can easily be considered not only a tool used by terrorist groups but also as the first viable step to helping radicalize potential recruits (Weimann, 2008). 


\section{Conclusion}

- Generally Social media has two side effects: positive and negative. The positive sides are, when peoples use social media for appropriate purpose and predetermined goals and the reverse is true for negative side effects.

- Now days due to technology advancement especially smart cell phone and mobile data, including elementary school students are using social media. so in addition to its benefits, these students might share its burdens( according to researchers the backsides of social media

\section{Implications}

- It is obvious that if consciously used social media has uncountable number of uses. But when it is without predetermined goal, it may grasp a lot of problems on us. So using of social media in responsible way for predetermined objective or goal is vital. For students who cannot manage themselves, education plays significant role. Providing awareness creation for example, the presence of social media addiction might save them from different effects.

- We can agree that information is power, but if it is used inappropriately it might exploit our life style. So parents should closely supervise and control while their children are using social media. Due to its cheap cost and availability and expansion of smart cell phone, many adolescents and children are using social media for a long period of time. This adversely affects their academic achievement.

- As much as the reviewer's knowledge is concerned, societies are using social media in religious institution, political meetings, in academic settings in the classroom while teachers are even teaching. In general, from root level to government all should have to work to save our culture from this media especially from Facebook.

\section{Declaration}

Ethics approval and consent to participate

Not applicable in this section.

Consent for publication

Not applicable" in this section.

\section{Availability of data and materials}

All data generated in this review are from published articles

\section{Competing interests}

The author declares that they have no competing interests.

Funding: Not funded

\section{References}

Bannink, Rienke; Broeren, Suzanne; van de Looij - Jansen, Petra M; Cyber and Traditional Bullying Victimization as a Risk Factor for Mental Health Problems and Suicidal Ideation in Adolescents. PLoS ONE. Apr2014, Vol. 9 Issue 4, p1-7.

Barnes, S. B. (2008). Understanding social media from the media ecological perspective. In E. A. Konijn, S. Utz, M. Tanis, \& S. B. Barnes (Eds.), Mediated interpersonal communication (pp. 14-33). New York: Rutledge.

Bhui, Kamaldeep, Brian Everitt, and Edgar Jones. "Might Depression, Psychosocial Adversity, and Limited Social Assets Explain Vulnerability to and Resistance against Violent Radicalisation?" PLoS ONE, 2014.

Boyd D. Taken Out of Context: American Teen Sociality in Networked Publics Berkeley, CA: University of California; 2008

Boyd D. Why youth (heart) social network sites:the role of networked publics in teenage social life. In Bucking ham D,ed. MacArthur Foundation Series on Digital Learning: Youth, Identity, and Digital Media Volume. Cambridge, MA: MIT Press; 2007.

Comm, J. (2010). Twitter power 2.0: How to dominate your market one tweet at a time . Hoboken: Wiley.

Choney, S. (2010) Facebook Use Can Lower Grades by 20 Percent, Study Says.

Dube, Dabi-Elle. "Internet, social media addiction linked to mental health risks: study." Health. Global News, 9 Sept. 2016. Web. 20 Jan. 2017.

DavilaJ, Stroud CB, StarrLR, et al. Romantic and sexual activities, parent-adolescent stress, and depressive symptoms among early adolescent girls. J Adolesc. 2009; 32(4):909-924

Faudree, M. R. (2009), Is Facebook a Useful Tool for College Students?. Retrieved April 1, 2012, fromhttp://www.manchester.edu/oaa/Programs/MISC/files/documents/Faudree Melissa-Paper.pdf

Ghulam et al,. The Impact of Social Media on Youth: A Case Study of Bahawalpur City Asian Journal of Social 
Sciences \& Humanities Vol. 3(4) November 2014 Leena and Luna International, Oyama, Japan

Ito M, Horst H, Bittani M Living and Learning With New Media: Summary of Findings From the Digital Youth Project. Chicago, IL:

Jacobsen, W. C., \& Forste, R. (2011). The Wired Generation: Academic and Social Outcomes of Electronic Media Use Among University Students. Cyber Psychology Behaviour \& Social Networking 18,(5) pp.6, 275-285

Jacobs, Tom; The Link Between Depression and Terrorism; SEP 29, 2014 http://booksandculture/antidepressants-depression-terrorism-weapon

Junco, R., Heibergert, G. \& Loken, E. (2010). The Effect of Twitter on college students Engagement and Grades, Journal of Computer Assisted Learning, pp 1-14

Kist, W. (2008). I gave up MySpace for lent: New teachers and social networking sites. Journal of Adolescent \& Adult Literacy" 52 (3) pp. 245.247

Krishna S, Boren SA, Balas EA. Healthcare via cell phones: a systematic review. Telemed E Health. 2009;15(3):231-240

Lenhart A. Cyberbullying. Washington, DC: Pew Research Center; 2007.

Lenhart, A., Ling, R., Campbell, S., \& Purcell, K. (2010). Teens \& mobile phones.Retrieved May 30, 2011 from Pew Internet \& American Life Project website:

Lusk, B. (2010) Digital Natives and Social Media Behaviors: An Overview. The Prevention Research, Vol. 17. pp 3-6.

Martin, J.L.,\& Yeung, K., (2006.) Persistence of close personal ties over a 12-year period.Social Networks; 28, pp 331-362.

MehMood, S, \& Taswir, T, (2013) The effect of social networking site on the Academic Performance on students in college of applies sciences, Nizwa, Oman. International Journal of Arts and Commence. Vol. 2 No. 1 pp 111-123

O'keeffe, G. S., and K. Clarke-Pearson. "The Impact of Social Media on Children, Adolescents, and Families." Pediatrics, 2011, 800-04

Patchin JW, Hinduja S. Bullies move beyond the school yard: a preliminary look at cyber- bullying. Youth Violence Juv Justice. 2006; 4(2):148-169

Saedi, Auzeen, Ph.D., (2012) Psychology Today; Millennial Media; The media saturated generation Y; "Catfish" and the Perils of Online Dating.

Sander Duivestein \& Thomas van Manen (2013) The Dark Side of Social Media Alarm bells, analysis and the way out, Research Institute for New Technology Text Book production, Groningen. The Netherlands

Weimann, Gabriel; The Psychology of Mass-Mediated Terrorism; American Behavioral Scientist. Sep2008, Vol. 52 Issue 1, p69-86. 18p 